\title{
ASSESSMENT OF DIVERSIFIED VEGETATION COMMUNITY IN ISLAMABAD VICINITY, PAKISTAN
}

\author{
I. Ashraf, T. Hussain, M. Jamil, I. Ahmad, M. Ahmad, G.H. Abbasi, \\ M. Akram, M.A. Sammar Raza, Researchers \\ University College of Agriculture \& Environmental Sciences \\ The Islamia University of Bahawalpur, Pakistan \\ E-mail: irfanmanj@gmail.com, ishtiaq507@gmail.com
}

Received December 17, 2012

\begin{abstract}
Islamabad is rich in diversified flora. This study was conducted to assess the vegetation communities of Islamabad vicinity. In present study seven different sites were selected in the vicinity i.e. CDA Nursery, F9 Park, Faisal Mosque, Jasmine Garden, near Prime Minister House, near Quaid-e-Azam University and Rawal Lake. A total of 62 major plant species were found in the study area. The dominance of plant species was estimated on basis of importance value. Most dominating species was Bros-

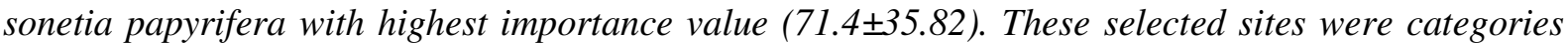
on the basis of specie richness indices and Shanen's diversity indices. Jinah Garden was rich in plant species on basis of specie richness.
\end{abstract}

\section{KEY WORDS}

Species; Dominant species; Broussonetia papyrifera; Nerium oleander; Flora; Jasminum; Dalbergia sissoo.

Plant properties deliver ingredients for survival of animals, medicinal, forage values, possess, and preserve cultural heritages, biological information and real knowledge about the vicinity (Hameed et al., 2011). Vegetation environment relationships disclose diverse fundamental processes that result in appearance of different vegetation patterns existing in urban ecosystems (Zeleny, 2008). In the recent Years, dumping of sewage wastes and garbage material has pronounced effects on the flora and fauna of the major reservoir. Due to accelerated urbanization and developmental activities in the recent Years, sewage wastes are being continuously discharged and dumped having adverse effect on soil environment (Chen et al., 2005). Distribution of species richness is likely to beregulated by two or more environmental gradients (Pausas and Austin, 2001). Species richness of urban ecosystem is determined mainly by environmental conditions and the species pool (Leps, 2004) which is usually less considered by decision makers and planners due to little knowledge of advantages provided by natural vegetation. Environmental variables can be classified into direct, indirect and resource gradients (Austin and Smith, 1989). Direct variables include factors such as soil characteristics that have a direct effect on vegetation (Tayler, 2003).

The Dalbergia sissoo, Acacia nilotica, Morus alba and Morus nigra were dominant tree species of the area 1960s which were eradicated as a result of human activities and introduction of some new plant species. The Broussonetia papyrifera invasion has been recognized as one of the major factors that has transformed the vegetation composition of the area from native to a mixture of introduced and native species. C.D.A has attempted to eradicate the plant by replacing it with some plant species of innate origin like Bauhinia variegata and Cassia fistula that are not only productive for wildlife but also does not harm the existing vegetation. Further, these are fast growing species (Imran, 2004).

The Murree area is quite rich in species diversity; with over 700 plant species were recorded many of them announced as endangered species (Ahmad and Javed, 2007). In Pakistan (Islamabad) there are three major types of forest existing regions are: i) subtropical pine forest at higher elevations, ii) Himalayan moist temperate forest at very limited area, and iii) deciduous broad-leaved forest at lower hills (Chaghtai et al., 1978). 


\section{MATERIALS AND METHODS}

The data on vegetation of the area was recorded with the help of square quadrats of $1 \times 1 \mathrm{~m}$ dimension taken at a distance of $10 \mathrm{~m}$ between the two quadrats along transact line $100 \mathrm{~m}$ in length; 20 such transacts laid at each study site with a distance at least $15 \mathrm{~m}$ between the two neighboring transact lines. For the vegetation with a height above $2 \mathrm{~m}$, larger quadrates $(10 \mathrm{~m} \mathrm{x}$ $10 \mathrm{~m}$ ) were laid with a distance of $10 \mathrm{~m}$ between the two neighboring quadrats to record the data, same transact used for two types of quadrats. The information recorded from each quadrat was plant species preset, number of plants belonging to each species and percent covered. These data was use to estimate percent composition, density and frequency for each plat species percent composition, density and frequency of each plat species. Various vegetation attributes were calculated according to the following formulae (Shabbir and Bajwa. 2006).

$$
\text { Relative Density }(\%)=\frac{\text { Number of quadrates in which a specie occurs }}{\text { Area samples (total number of quadrates) }} 100
$$

$$
\text { Relative Frequency }(\%)=\frac{\text { Number of quadrates in which a specie occurs }}{\text { Total number of quadrates sampled. }} \times 100
$$

$$
\text { Relative Cover }(\%)=\frac{\text { Area covered by a species in a quadrate }}{\text { Total area covered by all the species in a quadrat }} \times 100
$$

Importance Value (IV) = Relative Frequency + Relative Density

The plant communities were identified on the basis of dominant plant species i.e. species with the highest importance value.

\section{RESULTS AND DISCUSSION}

The human activity always has profound effect on the plant community of an area. Housing schemes and urbanization cause ecological changes in the flora. The increase in human population put heavy demand of land for infrastructure and result in the destruction and degradation of existing vegetation and inadequate planting sites (Jim, 2000). Rapid expansion of the cities engulf chunks of agriculture land and result in shrinkage of green spaces. The Green spaces are eventually distributed in the built-up areas if the areas are not planted and reserved primarily with the ecological aspect. (Feng et al., 2005).

Importance Indices. Brossonetia papyrife$r a$ (71.4) is dominating specie on the basis of overall mean Importance Value of all seven study sites, Figure 1 followed by Cynodon dactylon (36.4), Chrysopogon serrulatus (33.0), Acacia modesta (33.5), Desmostachya bipinnata (31.0), Diclyptera bupleuroides (26.1), Cannabis sativus (23.9), Dactyloctenum scindicum (20.9), Carthamus oxyacantha (19.8), Cymbopogon jwarancusa (19.1), Lantana camara (13.8), Justicia adhatoda (12.6), Dichanthium foveolatum (10.9),
Acacia nilotica (7.83), Prosopis glandulosa (7.61), Otostegia limbata (7.20), Conyza boneriensis (7.18), Sporobolus ioclados (6.93), Ziziphus nummularia (6.86), Cenchrus pennisetiformis (6.52), Trichodesma indica (6.51), Maytenus royleanus (6.24), Dichanthium annulatum (6.22), Grewia tenex (5.28), Periploca aphylla (5.22), Imperata cylindrical (4.97), Aristida mutabilis (4.52), Fagonia indica (4.23), Parthenium hystorophorus (4.03), Digitaria sanguinalis (3.87), Rhazia stricta (3.58), Calotropis procera (3.10), Olea ferruginea (3.12), Xanthium strumarium (2.95), Pupalia lappacea (2.71), Centaurea iberica (2.63), Ficus palmate (2.48), Heteropogon contortus (2.39), Eragrostis minor (2.28), Digitaria adescendens (2.00), Asparagus adscendens (1.89), Dodonaea viscosa (1.86), Enneapogon sp. (1.88), Lantana indica (1.88), Sporobolus arabicus, Aristida adscensionis (1.86), Phalaris minor, Phragmites karka, Saccharum bengalense (1.74), Solanum incanum (1.73), Abutilon fruticosum, Cyperus niveus (1.65), Buxus pappilosa (1.64), Boerhaavia diffusa (1.54), Launaea procumbens (1.53), Grewia villosa (1.46), Malvestrum coromendalianum, Nerium oleander, Pennisetum sp. (Cenchrus like), Dalbergia sissoo, Withania somnifera and Silybum marianum (1.44). The results of study under the process matches with that reported by Malik and Husain, (2007). 


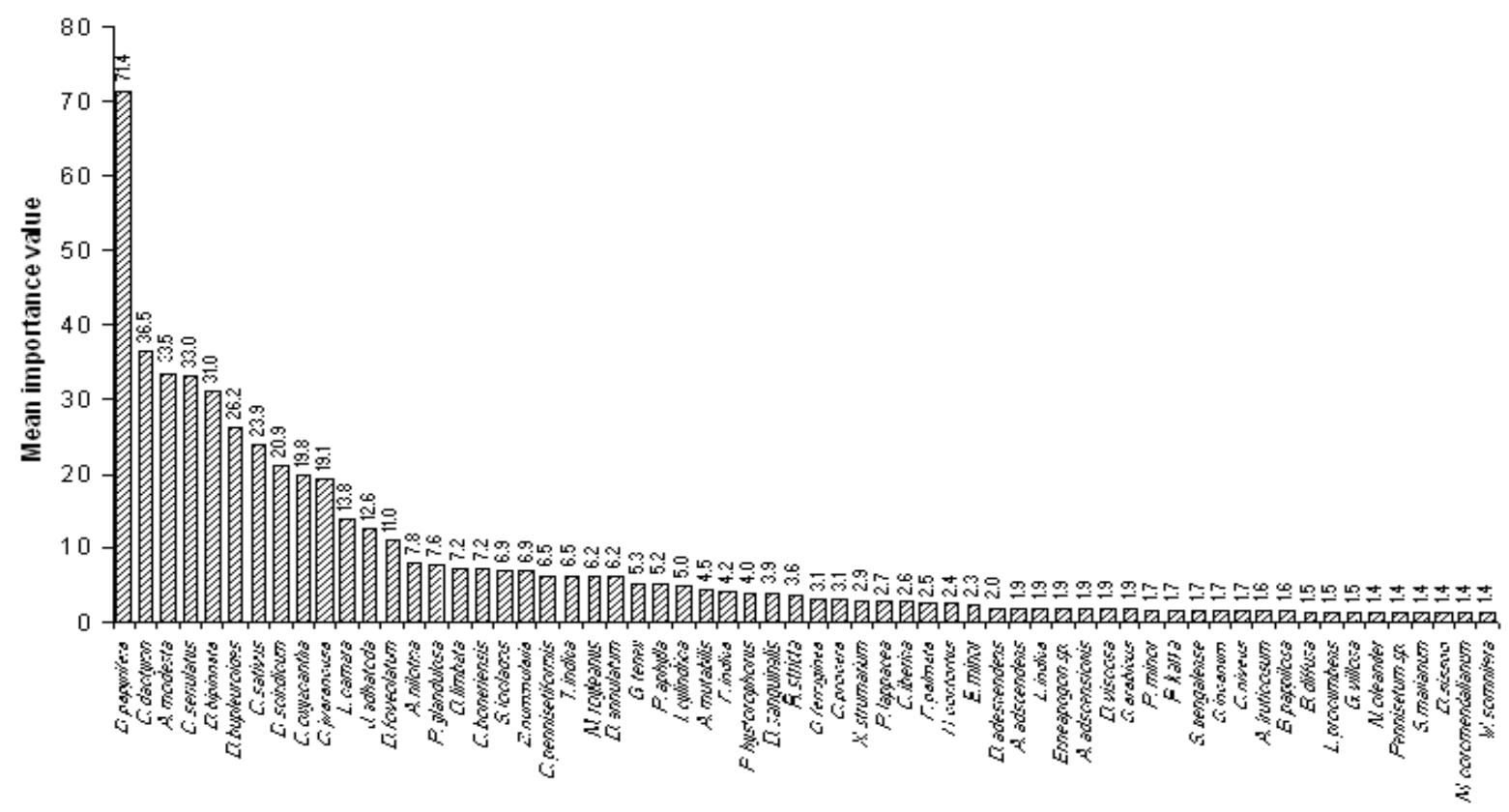

The plant species Broussonetia papyrifera has been recognized as one of the worst plants invaders highly impact species in Pakistan which flourishes along streams and drains due to presence of high moisture content that favors the vigorous growth. These species have the potential to less diversity and richness of woody as well as herbaceous species Khatoon and Ali, (1999). Although there are many factors which define the growth of vegetation, but generally vegetation dominance associated with greater water availability in areas (Malik and Husain, 2006). During February, up to April, proximity to Broussonetia papyrifera contributes to severe pollen allergy in Islamabad area which indicates that Broussonetia species are the most dominating specie (Birsel, 2007).

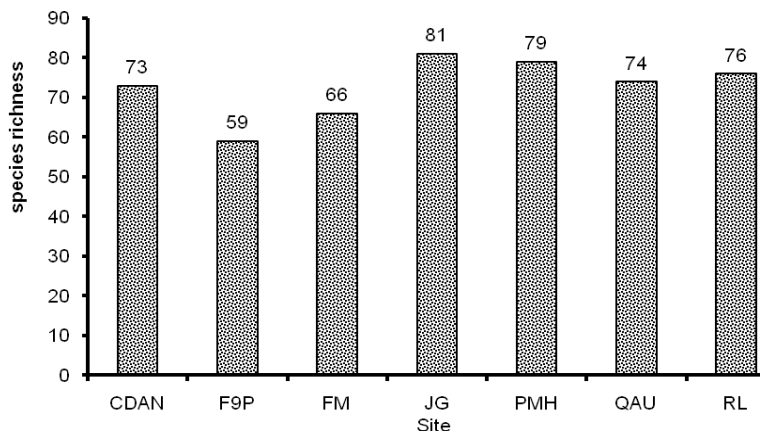

Figure 2 - Plant Richness at seven different study sites

The plant species richness at seven different sites is presented in Figure 2. The indices show that Jsmmine Garden was the richest specie site
(81) in among the seven study sites followed by the PMH (79), RL (76), QAU (74) and C.D.A-N (73) while Faisal Mosque (66) and F-9 Park was the poorer site (59) among the seven study sites.

Comparison of Plant Species Diversity on the basis Shannon's diversity indices. The plant abundance data among the seven sites was collected from $1 \times 1 \mathrm{~m}^{2}$ sizes of 10 sub-quadrates for herbs and 10 sub-quadrates of $5 \times 5 \mathrm{~m}^{2}$ for tress for each study site. A uniform distance, with-in each study site was used to calculate the diversity indices, frequency and density indices.

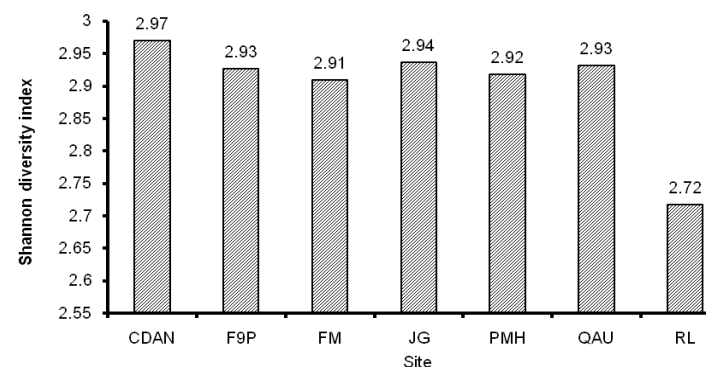

Figure 3 - Comparison of plant species diversity at seven different study sites by Shannon's diversity indices estimated by computer software Estimates 8.0

The Comparison of the Shannon's Diversity Indices for plant communities at seven different study sites, (C.D.A-N) C.D.A-Nursery, (F-9P) F9 Park, (FM) Faisal Mosque, (JG) Jasmine Garden, (PMH) Prime Minister House, (QAU) Quaid-e-Azam University and (RL) Rawal Lake is presented in Figure 3. The order of diversity at 
study sites was as follows C.D.A-N (2.97), JG (2.94), F-9P and (QAU) (2.93), PMH (2.92), FM (2.91) and RL (2.72). However, this Indies was similar for whereas with respect diversity indices, F-9 park and Quid-e-Azam University sites. Several diversity ideas exist in the ecological litera- ture. The Shannon index is based on percentage composition by species (Shannon and Weaver 1949). The other most commonly applied ideas are Combines Species Richness, Number with Equitability, and Evenness, with which individuals are distributed among species.

\section{REFERENCES}

Ahmad, S.S. and S. Javed. 2007. Exploring the economic valueof underutilized plant species in Ayubia National Park. Pak. J. Bot., 39: 1435-1442.

Austin, M.P. and T.M. Smith. 1989. A new model for the continuum concept. Vegetatio, 83: 35-47.

Birsel, R. 2007. Mulberry trees bringing misery to Pakistani city. The Dawn News. March 05,2007.

Chaghtai, S.M., S.H. Shah and M.A. Akhtar. 1978. Phytosociological studies of the graveyars of Peshawardistrict, NWFP. Pak. J. Bot., 10: 17-30.

Chen, T.M., Y.M. Zheng, M. Lei, Z.C. Huang, H.T. Wu, H. Chen, K.K. Fan, K. Yu, X. Wu and Q.Z. Tian. 2005. Assessment of heavy metal pollution in surface soils of urban parks in Beijing,China. Chemosphere, 60: 542--551.

Feng, Li., R. Wang, J. Paulussen and X. Liu. 2005. Comprehensive concept planning of urban greening based on ecological principles: A case study in Beijing, China. Landscape.Urb.Plan., 72: 325-336.

Hameed, M., M. Ashraf, F. Al-Quriany, T. Nawaz, M. S. A.Ahmad, A. Younis and N. Naz. 2011. Medicinal flora ofthe Cholistan desert: A review. Pak. J. Bot., 43: 39-50.

Jim, C.Y. 2000. The urban forest programme in the heavily built up milieu of Hong Kong. Cities. 17:271-283

Khatoon, S. and S.I. Ali. 1999. Alien Invasive Species in Pakistan, University of Karachi, Pers.Comm., Pakistan.
Leps, J. 2004. What do the biodiversity experiments tell us about consequences of plant speciesloss in the real world? Basic. App. Ecol., 5: 529-534.

Malik, R.N. and S.Z. Husain. 2006. Classification and ordination of vegetation communities of the Lohiber reserve forest and its surrounding areas, Rawalpindi, Pakistan. Pak. J. Bot., 38: 543-558.

Malik, R.N. and S.Z. Husain. 2007. Broussonetia papyrifera (L.) Her. Ex. Vent: An environmental constraint on the Himalayan foothills vegetation. Pak. J. Bot., 39(4): 1045-1053.

Pausas, J.G. and M.P. Austin. 2001. Patterns of plant species richness in relation to differentenvironments. J. Veg. Sci., 12: 153166.

Shabbir, A. and R. Bajwa. 2006. Distribution of Parthenium weed (Parthenium hysterophorus L.), an alien invasive weed species threatening the biodiversity of Islamabad. Weed Biol. Manag., 6: 89.

Shannon, C. E., and W. Weaver. 1949. The mathematical theory of communication. Univ. Illinois Press, Urbana. 117 p.

Tayler, G. 2003. Some ecophysiological and historical approaches to species richness andcalcicole / calcifuge behavior - contribution to a debate. Folia Geobotanica, 38: 419-428.

Zeleny, D. 2008. Patterns of vegetation diversity in deep river valleys of the Bohemian Massif.Ph.D Thesis.Faculty of Science. University of South Bohemia, Czech Republic. pp. 126. 